\title{
STEEL LATTICE TOWER UNDER ULTIMATE LOAD - CHOSEN JOINT ANALYSIS
}

\author{
Jacek SZAFRAN ${ }^{1}$, Kazimierz RYKALUK ${ }^{2}$ \\ ${ }^{1}$ Łodz University of Technology, Łódź, Poland \\ ${ }^{2}$ Wroclaw University of Environmental and Life Sciences, Wrocław, Poland
}

\begin{abstract}
The main objective of the presented paper is to discuss chosen lattice tower joint behavior under structure ultimate load. Joint numerical modelling considerations are enriched with comparison to the full-scale tower pushover test results. Two independent load cases were examined: 1) where the L-sections (diagonal bracings) are loaded by the axial force only and that forces are applied in the center of the member cross section, 2) where the L-sections are loaded by the axial force and the bending moment that reproduce the effect of the eccentric connection to the gusset plates by the one leg of the angle section is added. Differences in equivalent stresses state for two independent design situations allow for conclusion that additional bending moments should be taken into account, especially for thin-walled members.
\end{abstract}

Keywords: steel lattice tower, L-section, Finite Element Analysis, structural joint, fullscale test, eccentricity of load

\section{INTRODUCTION}

Individual steel elements made with hot-rolled L-sections are used in numerous engineering structures (such as plane and space trusses), various telecommunication structures (towers, masts $[7,8]$ ), or transmission towers.

\footnotetext{
${ }^{1}$ Corresponding author: Department of Structural Mechanics, Chair of Reliability of Structures, Faculty of Civil Engineering, Architecture and Environmental Engineering, Łódź University of Technology, Al. Politechniki 6, 90-924 Łódź, Poland

2 Corresponding author: The Faculty of Environmental Engineering and Geodesy, Wrocław University of Environmental and Life Sciences, C. K. Norwida st 25, 50-375 Wrocław, Poland
} 
Single L-sections are also used as truss elements for multiple struts. They are popular because of easiness of attaching them to other structural members. They are almost always connected eccentrically at their ends. In most practical applications, angles are loaded through one leg only thus introducing eccentricity with respect to the center of the cross section. At the same time restraining moments at the ends of the member are also present due to the flexural rigidity of the connected elements. In a rational design philosophy, the detrimental effect of the end eccentricity and the advantageous effect on the compression capacity of the end restraint of angle members should be addressed [4]. Taking the above into consideration, it can be stated that designing such steel elements should be based on knowledge regarding their behavior under breaking load. Parameters like asymmetry of cross sections and eccentric loading along with end restraint should also be taken into account. Galambos in [4] indicates that end eccentricities cause biaxial flexural deformation of the strut at any given load, therefore the main research challenge for this case is load-deformation response.

Utilization of eccentrically connected angle section members is common for transmission and telecommunication towers. Work of Alberamani et al. [1,2] was devoted to creation of a numerical model which allowed for prediction of transmission tower failure. A pushover test of a single, 10 meter transmission tower section consisting of angle beams with typical eccentric connections in order to depict a phenomenon of large deformations was a part of publication of $[5,6]$.

The presented paper is the extension of the authors' previous works $[9,10]$ where the behavior of the $\mathrm{X}$ pattern diagonal bracings in the lattice tower subjected previously to the full-scale pushover test was analyzed and described in details. The main goal here is to check the stress state for one particular structural joint (leg-diagonal bracing connection in the middle span of the tower lowest section) in two calculational situations.

\section{EXPERIMENTAL FULL-SCALE TEST}

The experiment was carried out in December, 2014. A controlled destruction of a 40 meter, lattice telecommunication tower was performed taking into consideration several objectives:

- the identification of the failure mechanism of the tower members with particular regard to the diagonal bracing elements and joints behavior,

- the measurements of strains with electric resistance strain gauges placed on diagonal bracing elements of the spatial truss. 


\subsection{Structure description}

The tower body was manufactured as a three-dimensional truss of a triangular cross-section and height of 40,0 meters divided into seven sections. Its upper part was of a triangular cross-section and the bottom part (up to $34^{\text {th }}$ meter) formed a pyramid frustum with constant $5 \%$ convergence (Fig. 1).
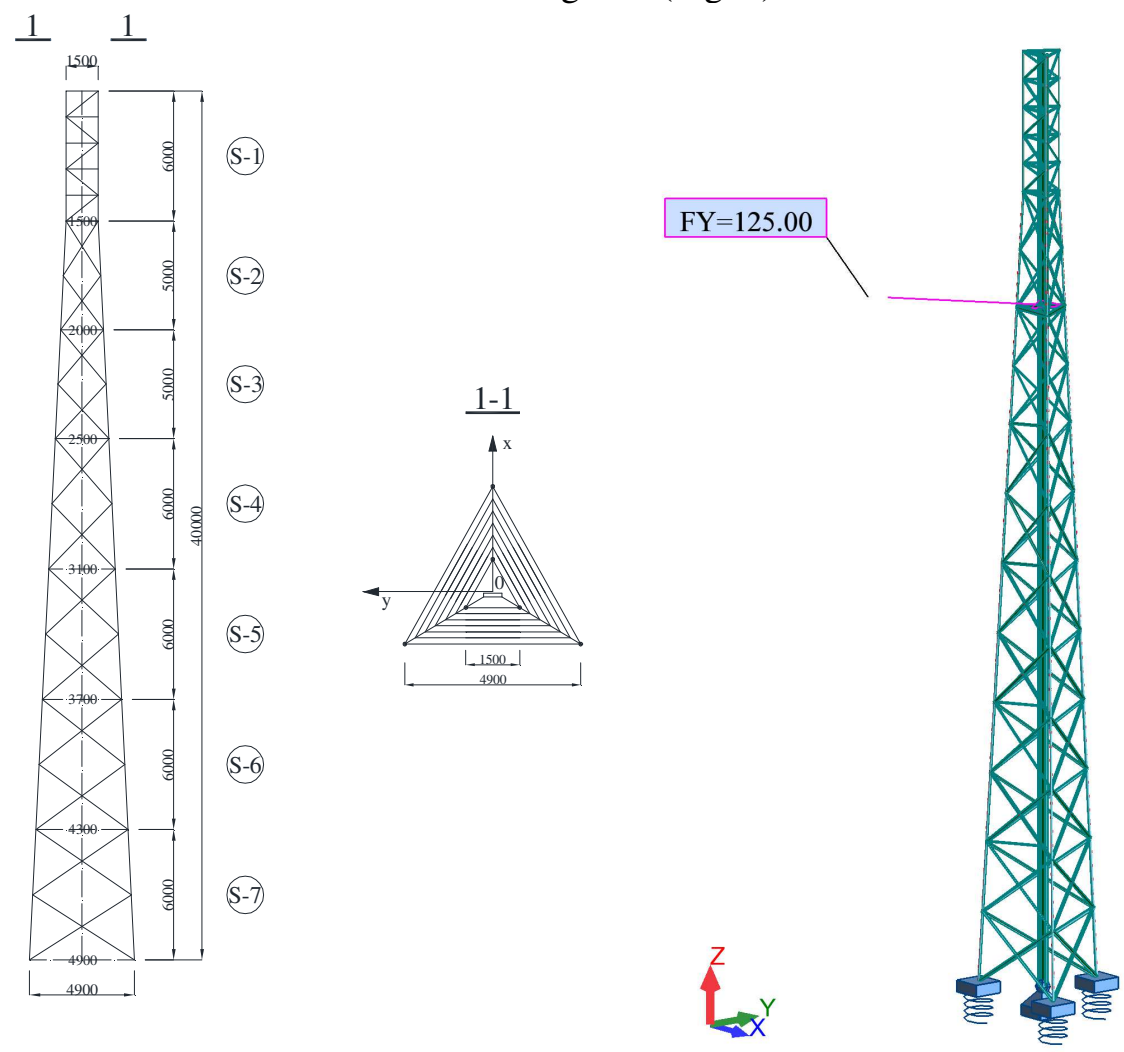

Fig. 1. Static scheme of the tower (left), tower cross section (middle) and the FE numerical model (right)- unit is $\mathrm{mm}$

The centerline dimension was 4,90 $\mathrm{m}$ at its base and 1,50 $\mathrm{m}$ at its top. The leg members in each section consisted of round solid bars, and bracing elements of hot-rolled equal leg and unequal leg angles. Diagonal bracing system of the tower was of type X. The bracing elements were continuous in structure and the joints at their intersections were made with a spacer and a single bolt. Their connections with tower legs (round solid bars) were realized with gusset plates and bolts, two for a connection (see Fig.2).

Is worth to underline the fact that connection presented in Fig. 2 (right) is the joint that was subjected to the numerical tests in the next part of the manuscript. 



Fig. 2. Connections of diagonal bracing members with tower legs in mid span of the section $\mathrm{S}-7$

\subsection{Material properties}

In order to determine the mechanical properties of the structural steel, tensile testing of 6 sample L-sections and legs was performed according to standard [3]. Mechanical properties obtained during the laboratory tests are listed in Table 1.

Table 1. Mechanical properties of structural steel

\begin{tabular}{|c|c|c|}
\hline \multirow{2}{*}{ Mechanical properties } & \multicolumn{2}{|c|}{ Values } \\
\cline { 2 - 3 } & Bracing & Legs \\
\hline Experimental Young's modulus & $202,0 \mathrm{GPa}$ & $206,7 \mathrm{GPa}$ \\
\hline Experimental yield strength & $294,2 \mathrm{MPa}$ & $282,1 \mathrm{MPa}$ \\
\hline Experimental tensile strength & $399,8 \mathrm{MPa}$ & $449,7 \mathrm{MPa}$ \\
\hline
\end{tabular}

\section{EXPERIMENTAL RESULTS - FAILURE MECHANISM AND FAILURE MODES}

One of the goals of the experiment was the observation of failure mechanism of the structure under ultimate external load. In order to attain this goal, the test was recorded with high definition cameras placed within the body of the tower and at various locations over the experimental site. The failure mechanism analysis was assumed to show which of the elements would give in o the destruction first: $\operatorname{leg}(\mathrm{s})$ of the tower, bracing member(s), weld(s), tensioned bolts, flanges or gusset plates. The video presenting the failure mechanism is available online and can be accessed via link at https://www.youtube.com/watch?v=DLor2U-fREs. 

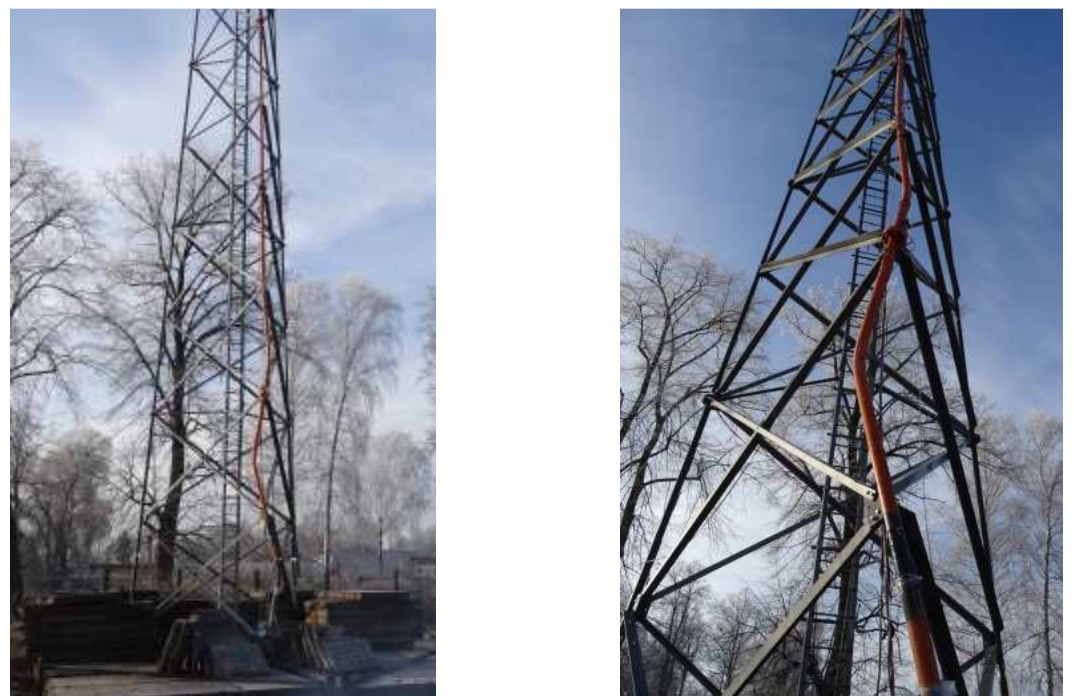

Fig. 3. Buckling of the leg in section S-7 of the tested tower - general (left) and detailed (right).

The buckling of the leg (round solid bar with diameter equal to $100 \mathrm{~mm}$ ) in section S-7 was the first element of the tower to get destroyed. It is worth noting that the buckling of the leg occurred perpendicularly to the loading force. Plastic hinges occurred at the centers of bracing panels: at $1 / 4$ and $3 / 4$ of section's span. Moreover, the joint connecting sections S-7 and S-6 remained rigid. The leg after buckling with visible plastic deformation is presented in Fig. 3.
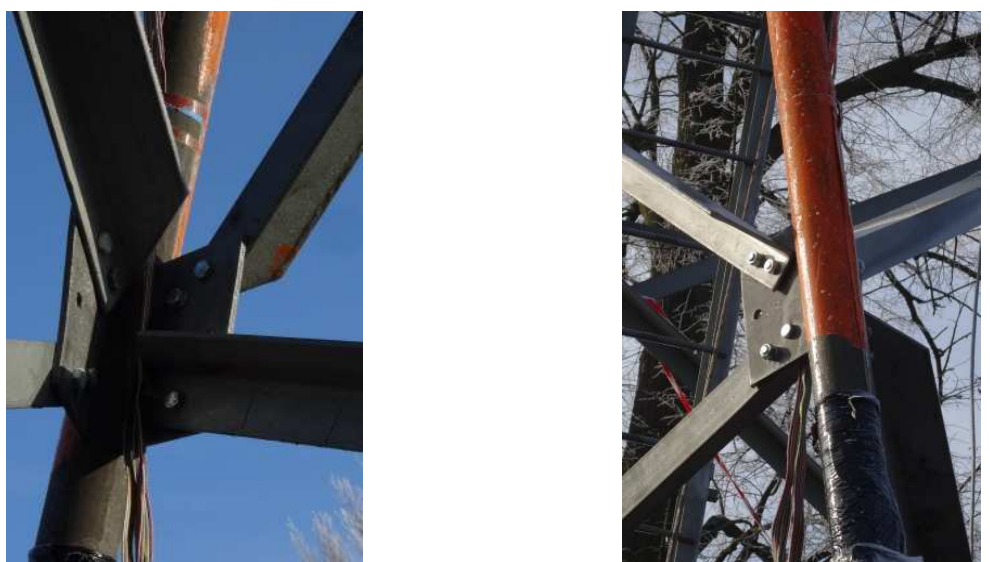

Fig. 4. Deformed gusset plates in middle span of the leg in the lowest section.

As a result of the leg buckling at section S-7, joints connecting diagonal bracings with the legs were subjected to vertical displacement towards foundations of the 
tower. An eccentric connection of gusset plates and angles caused strain at bracing members' ends.

It should be highlighted that rupture in the cross-sections around the bolt holes did not take place due to considerable dimensions of L-sections in this segment of the tower. The bolts themselves, 2 x M16x45 (8.8), were not damaged either. The greatest deformation could be noticed on gusset plates (thickness $10 \mathrm{~mm}$ ) at the half of the leg's length. They were twisted by bracing members that were during the buckling of the leg. It is obvious that the method of connection (two screws in a rigid way) also played a part. The deformed shape of the gusset plate after the buckling of the leg is presented in Fig. 4 above.

\section{JOINT FE ANALYSIS}

\subsection{Tower numerical model}

Tower computational model have been prepared in the civil engineering FEM software Autodesk ROBOT Structural Analysis with the use of 222 3D linear beam finite elements connected in 278 nodal points, where all structural connections - in-between the legs sections as well as in-between the legs and rebars (two bolts of the class 8.8 ) have been set as completely rigid. Additionally, the geometrical imperfections have been added to the legs in two lower segments (S-7 and S-6) that have been measured before the experiment - these are about 15 $\mathrm{mm}$ for the legs in S-7 as well as about $8 \mathrm{~mm}$ in the section S-6. These initial deformations have been noticed in the midspan of these elements, so that in a location of the gusset plates and their computational implementation has been made by replacing perfect geometry with adding the new finite elements fitting curvilinear deformed shape in-between the original connections; therefore, the resulting displacements are given in addition to the original geometry. Finally, compatible nodes have been inserted in all the crossings within the X patterns of the tower rebars. Moreover, an application of the elastic supports (connections with the foundation) has been implemented. Compliance coefficient has been detected on the basis of real displacements of the supporting joints for the uploading level $125,0 \mathrm{kN}$, for each support independently. Geometrically nonlinear analysis has been performed (the so-called P- $\Delta$ analysis) according to the well-known BFGS algorithm; the final FE model is presented in Fig. 1.

\section{2. $\quad$ Leg - diagonal bracing joint}

To further computational analysis the joint where compressed leg in section S-7 (100 mm diameter) and diagonal bracings in form of L-sections are connected was chosen. The position of this particular joint is presented in Fig. 2. Main characteristics of the connection are as follows: connection is placed in the mid 
span of the tower lowest leg, the leg is under compression, the plates welded to the leg may be treated here as a stiff elements with thickness equal to $10 \mathrm{~mm}$, throat of fillet welds are equal to $5 \mathrm{~mm}$, L-sections of the diagonal bracing have size 120x80x8 (bottom level) and 100x75x8 (upper level), connection between plates and L-sections is realized by two bolts M16 class 8.8. Presence of two bolts on one panel of each L-section causes that angles are loaded through one leg only - classical theory of truss members is not allow to be applied in this case.

To create numerical model of considered joint (Fig. 5) IDEA STATiCa software was used [11]. Computer program uses shell finite elements with six degrees of freedom in every node ( 3 translations, 3 rotations). Deformations of the element are divided into membrane and flexural components.
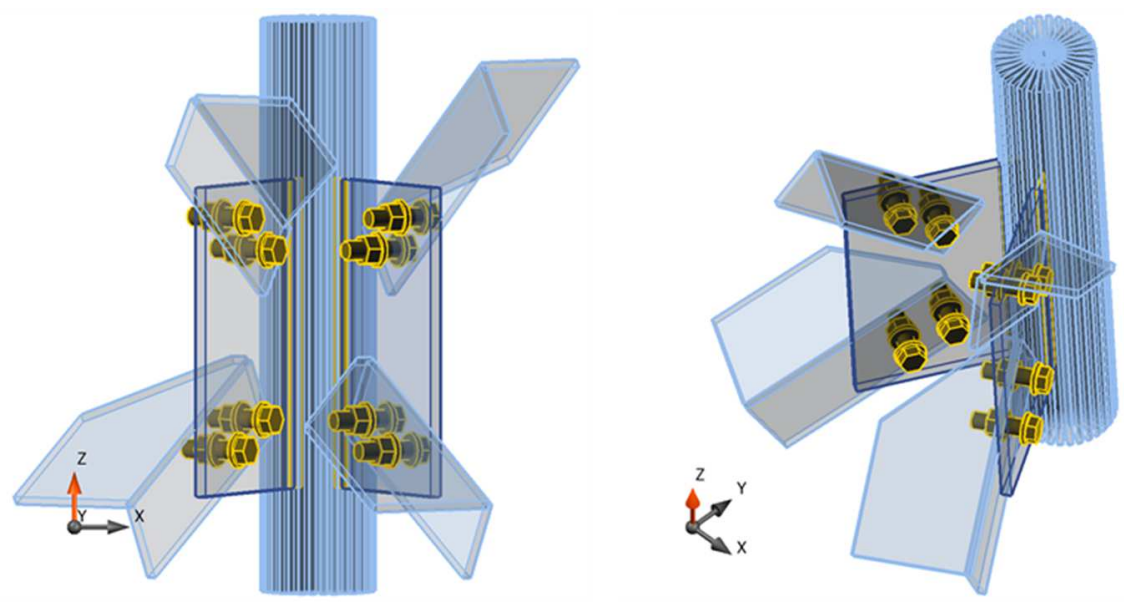

Fig. 5. Numerical model of the analyzed joint

In computational study we have compared stress state for individual elements of the examined structural joint. In Fig. 6 there are presented two independent load cases.

First load case is defined as follows: leg of the section S-7 is loaded mainly by the axial compression force ( $816 \mathrm{kN}$ at the top and $862 \mathrm{kN}$ at the bottom) and residual moments $(0,1-0,7 \mathrm{kNm})$. All internal forces are taken directly from calibrated tower global model described above. Diagonal bracings are loaded by the axial forces only (compression at the upper level and tension at the bottom level - values are equal to $18,2,18,4 \mathrm{kN}$ and $19,6,19,3 \mathrm{kN}$ respectively). Axial forces are applied at the center of the angles cross sections.

Second load case include all aforementioned internal forces enriched with bending moments that results from attaching L-sections by two bolts at the one panel only. It is worth to emphasize the fact that in classical FE models created with truss or beam finite elements those eccentricity effects are not included 
automatically and should be added to the analysis. Load states details are given in Fig. 7 - first load case (left) and second (right).
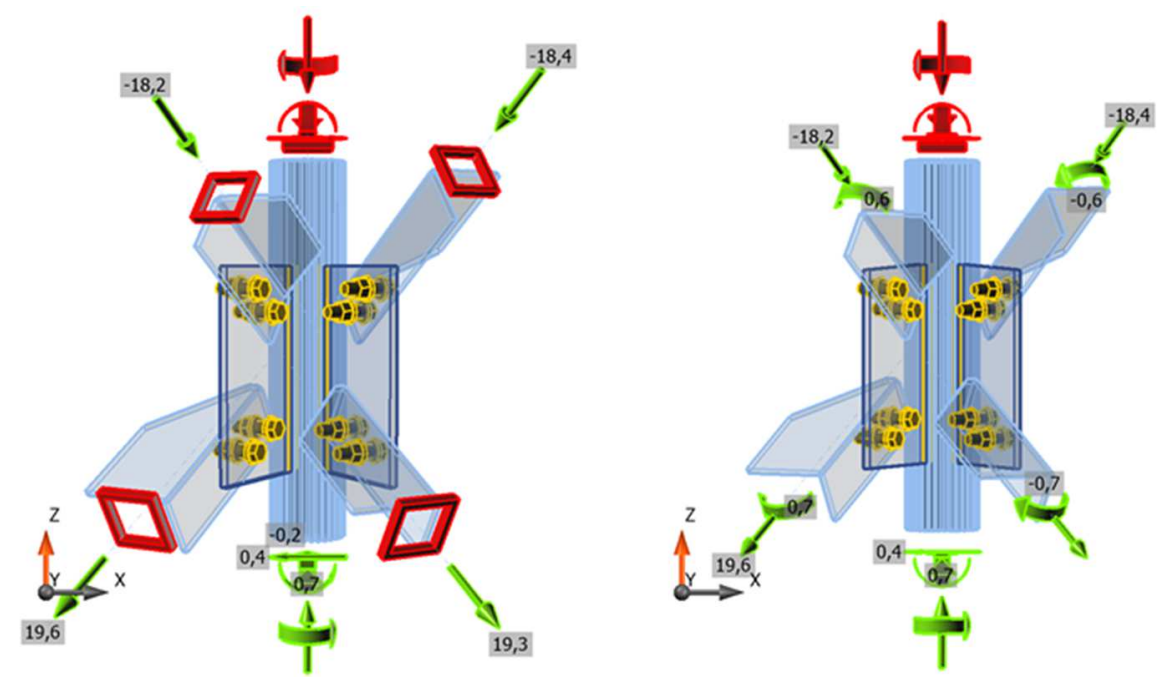

Fig. 6. The first (left) and the second (right) load case

Equivalent stresses for considered structural joint for first and second load case are depicted in Fig. 7 - left and right respectively. As we can observe equivalent stresses do not reach the limit values what is caused mainly by the significant stiffness of joint resulting from thickness of the connected members, throat of fillet welds and etc. Taking into account the fact that joint internal forces are calculated for the tower external load equal to $125 \mathrm{kN}$ those results coincide with the observations taken at the tower full-scale test.
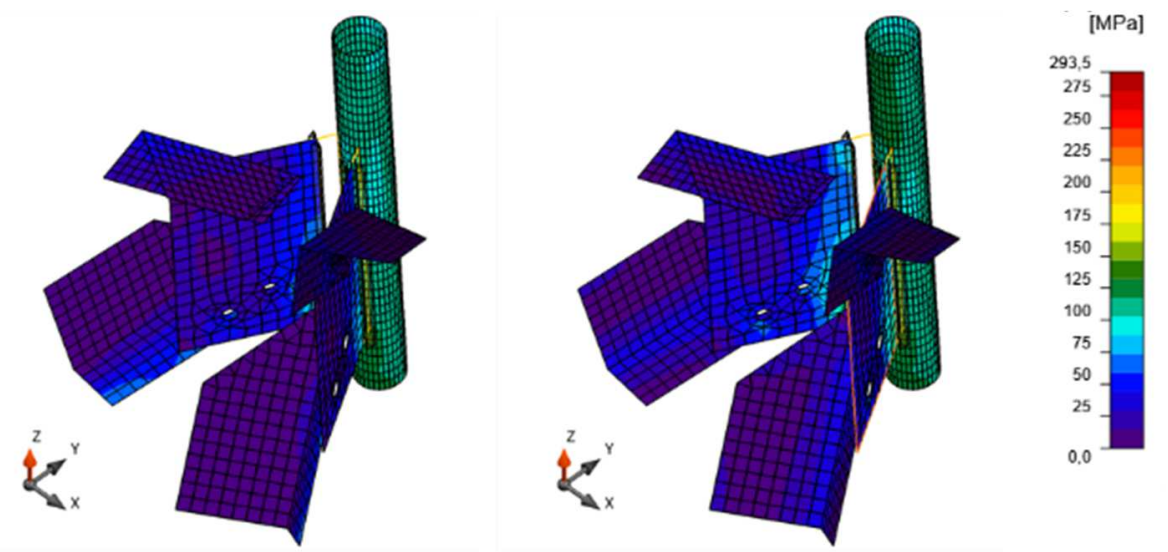

Fig. 7. Equivalent stresses for first (left) and second (right) load case 
The equivalent stress differences between first and second load case are illustrated in Fig. 8 - in case of gusset plates with bolt holes. We can observe that stresses increase when approaching fillet welds what is especially reflected at the second numerical approach. Certainly the values are still small (around 100-115 MPa) but it must be stated that plate thickness is rather significant in analyzed case.
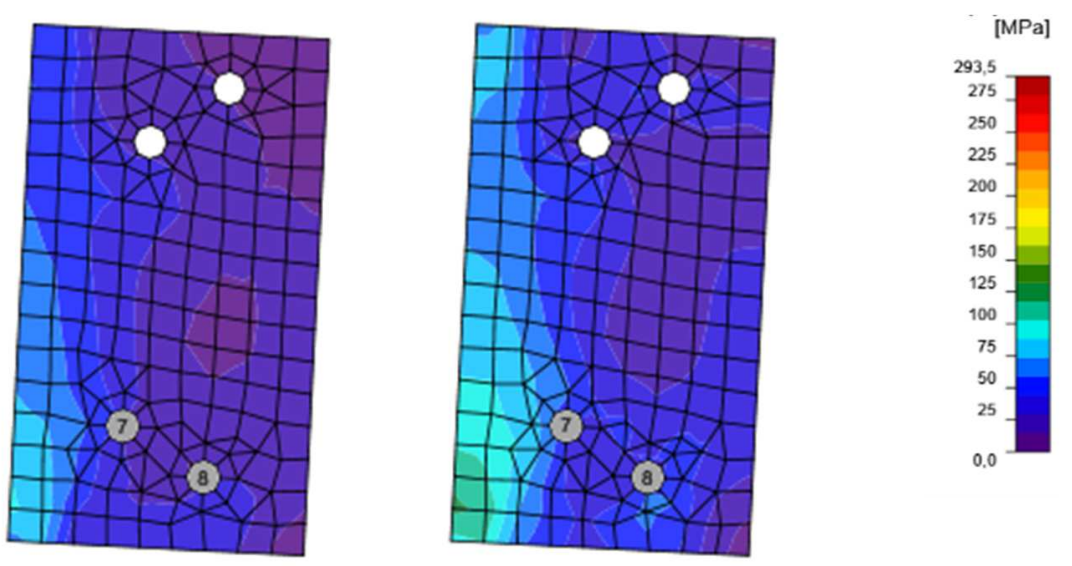

Fig. 8. Distribution of the equivalent stresses in the gusset plate for first (left) and second (right) load case

Similar situation may be observed at the L-section panel with bolt holes that is given in Fig. 9. Additional bending moments affected steel members near the second bolt holes what also was noted during the after experiment inventory. Perpendicular L-section panels (those without bolt holes and with chamfered ends) almost completely not transfer any stresses what also corresponds to the engineering intuition and practice.
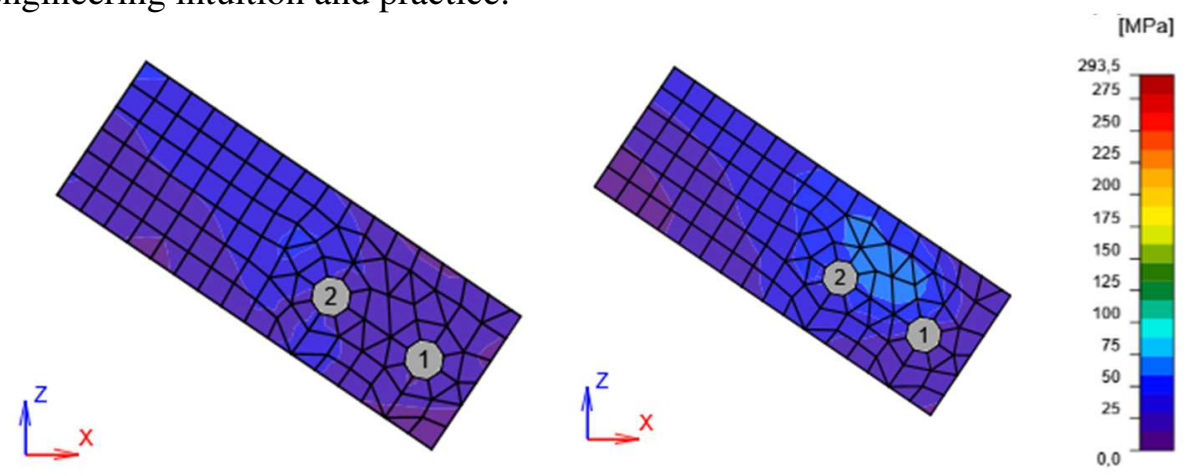

Fig. 9. Distribution of the equivalent stresses in L-section panel with bolt holes for first (left) and second (right) load case 


\section{CONCLUSIONS}

The results presented in the article allow for drawing the following conclusions. It can be stated that the reliability of the tower structure, which was subjected to a pushover test, was without doubt dependent on bearing capacity of its legs. As presented above, the first symptom of failure of the structure was buckling of the leg at a bottom section of the tower.

The advantage of the performed numerical tests is the structure internal forces determination for individual members on the basis of the entire tower calibrated FE model. Model has been calibrated after full-scale test structural responses such as displacements and stresses. It helped to create the numerical model of joint with application of the forces taken directly from entire tower FE model.

Results in form of equivalent stresses for analyzed joint were obtained for value of the external load equal to $125 \mathrm{kN}$. That level of loading applied to the tower structure did not cause excessive strains and stresses in gusset plates nor diagonal bracings which have been proven by the observation of the structure failure mechanism. It allows us to conclude that values of stresses for particular members of the analyzed joint are defined correctly.

It also must be clearly stated that the effect of the bending moment (resulting from eccentricity of loading with respect to the center of the cross section) in connections by the one leg of the L-section should be definitely taken into account in bearing capacity estimation. It is extremely important especially in cases with slender and thin-walled L-sections or gusset plates.

\section{REFERENCES}

1. Albermani F., Kitipornchai S., Chan R.W.K.: Failure analysis of transmission towers, Engineering Failure Analysis, 16 (2009) 1922-1928.

2. Albermani F., Mahedran M., Kitipornchai S.: Upgrading of transmission towers using diaphragm bracing system, Engineering Structures, 26 (2004) 735-744.

3. EN ISO 6892-1: Metallic materials - Tensile testing - Part 1: Method of test at the room temperature. Brussels, European Committee for Standardization 2009.

4. Galambos T.V.: Guide to stability design criteria for metal structures, New York, John Wiley \& Son 1998.

5. Lee P.S., McClure G.: A general three - dimensional L-section beam finite element for elastoplastic large deformation analysis, Computers and Structures 84 (2006) 215-229. 
6. Lee P.S., McClure G.: Elastoplastic large deformation analysis of lattice tower structure and comparison with full-scale tests, Journal of Constructional Steel Research 63 (2007) 709-717.

7. Rykaluk K.: Steel structures. Chimneys, towers, masts (in Polish), Wrocław, Oficyna Wydawnicza Politechniki Wrocławskiej 2004.

8. Smith B.W.: Communication structures, London, Thomas Telford Publishing 2007.

9. Szafran J., Rykaluk K.: Diagonal bracing members of lattice towersanalytical versus experimental studies, in: Recent Progress in Steel and Composite Structures, edit. M. Giżejowski, A. Kozłowski, J. Marcinowski, J. Ziółko, Zielona Góra, CRC Press/Balkema Taylor\&Francis Group 2016, 9495.

10. Szafran J., Rykaluk K.: A full-scale experiment of a lattice telecommunication tower under breaking load, Journal of Constructional Steel Research, 120, (2016) 160-175.

11. Wald F. et al.: Benchmark cases for advanced design of structural steel connections, Praha, Ĉeska Technika ĈVUT 2016.

\section{STALOWA WIEŻA KRATOWA POD OBCIĄŻENIEM NISZCZĄCYM - ANALIZA WYBRANEGO WĘZEA}

\section{Streszczenie}

Przedmiotem niniejszego opracowania jest analiza naprężeń wybranego węzła stalowej wieży kratowej, która podlegała obciążeniu niszczącemu. Przeprowadzona analiza numeryczna dotyczyła modelowania wybranego węzła konstrukcji - połączenie elementów skratowania wykonanych z kątowników nierównoramiennych z krawężnikiem wieży (stalowy pręt pełny o średnicy $100 \mathrm{~mm}$ ). Charakterystyczną cechą wybranego połączenia jest zamocowanie kątowników skratowania do blachy węzłowej poprzez dwie śruby umiejscowione tylko na jednej półce kątowników. Przeprowadzono analizę obliczeniową dla dwóch niezależnych przypadków obciążeniowych: 1) sytuacja, w której elementy kątownikowe skratowania obciążone są jedynie siłami osiowymi (ściskającymi i rozciągającymi) przyłożonymi w środku ciężkości, 2) sytuacja, w której oprócz opisanego powyżej przypadku sił osiowych dodano momenty zginające wynikające wprost z mimośrodu obciążenia osiowego względem rzeczywistego miejsca zamocowania kątowników. Zaprezentowane rezultaty naprężeń zredukowanych dla każdej z analizowanych sytuacji obliczeniowych pozwalają na stwierdzenie, że należy brać pod uwagę dodatkowe momenty zginające powstałe w wyniku mimośrodowego zamocowania prętów kątownikowych - szczególnie, kiedy są to elementy cienkościenne. Co szczególnie istote $\mathrm{z}$ punktu widzenia praktyki inżynierskiej i badań naukowych, uzyskane wyniki zostały porównane $\mathrm{z}$ obserwacjami poczynionymi podczas testów 
eksperymentalnych polegających na kontrolowanym zniszczeniu konstrukcji wieżowej w jej skali naturalnej.

Słowa kluczowe: stalowe wieże kratowe, kątowniki stalowe, Metoda Elementów Skończonych, połączenia, testy konstrukcji w skali naturalnej, mimośród obciążenia

Editor received the manuscript: 12.07 .2016 